\title{
Bir olgu nedeniyle varicella zoster ensefaliti ve tüberküloz menenjit birlikteliği
}

\author{
Coexistence of varicella zoster encephalitis and tuberculous \\ meningitis due to a case
}

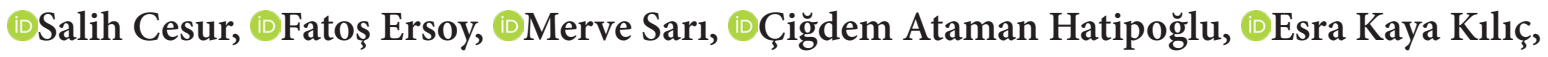 \\ 독ami Kinıklı \\ Sağlık Bilimleri Üniversitesi, Ankara Eğitim ve Araştırma Hastanesi, Enfeksiyon Hastalıkları ve Klinik Mikrobiyoloji Kliniği, Ankara, Türkiye
}

Cite this article as/Bu makaleye atıf için: Cesur S, Ersoy F, Sarı M, Ataman Hatipoğlu Ç, Kaya Kılıç E, Kınıklı S. Bir olgu nedeniyle Varicella zoster ensefaliti ve tüberküloz menenjit birlikteliği. J Med Palliat Care 2021; 2(4): 149-152.

\section{ÖZ}

$\mathrm{Bu}$ yazıda literatürde nadiren bildirilen bir durum olan varicella zoster ensefaliti ile tüberküloz menenjiti birlikteliği olan 58 yaşında erkek hasta sunuldu. Orbitofrontal bölgede zona tanısıyla valasiklovir tedavisi alırken hastada varicella zoster virüse bağlı olarak ensefalit kliniği gelişti. Tedavi sonrası ateşinin düşmemesi üzerine yapılan incelemelerde beyin omurilik sıvısında polimeraz zincir reaksiyonu testinde Mycobacterium tuberculosis kompleks'in pozitif saptandı. Hastaya tüberküloz menenjit tanısı konuldu. Tedavi sonrasında hastanın ateşi ve klinik yakınmaları tamamen düzeldi.

Anahtar Kelimeler: Varicella zoster ensefaliti, tüberküloz menenjit, koenfeksiyon

\begin{abstract}
In this article, a 58-year-old male patient with coexistence of varicella zoster encephalitis and tuberculous meningitis, a condition rarely reported in the literature, is presented. While receiving valacyclovir treatment with the diagnosis of shingles in the orbitofrontal region, the patient developed encephalitis clinic due to varicella zoster virus. In the examinations made after the fever did not decrease after the treatment, the polymerase chain reaction test in the cerebrospinal fluid was positive for Mycobacterium tuberculosis complex. The patient was diagnosed with tuberculous meningitis. After the treatment, the patient's fever and clinical complaints completely resolved.

Keywords: Varicella zoster encephalitis, tuberculous meningitis, coinfection
\end{abstract}

\section{Gíriş}

Varicella zoster virüs (VZV), Herpesviridae ailesinde yer alan çift iplikli, zarflı bir DNA virüsüdür. VZV, primer enfeksiyonu olan suçiçeğinin sonrasında dorsal kök gangliyonlarında latent olarak kalır; reaktivasyonu sonucunda rekürren enfeksiyonu olan herpes zoster (zona) ortaya çıar. VZV reaktivasyonu sonuucnda ensefalit, menenjit, Ramsay Hunt sendromu, serebellit, myelit ve serebrovasküler olayla ilişkili sendromlar gibi klinik tablolar görülebilir $(1,2)$. VZV’nün tüm yaş gruplarında herpes simpleks virüs (HSV)'ünden sonraki en yaygın viral ensefalit etkeni olduğu bildirilmiştir. VZV ile ilişkili ensefalitte mortalitenin tedaviyle
\%5-20 arasında değiştiği, hayatta kalan hastalarda ise hafif veya şiddetli çeşitli nörolojik sekellerin geliştiği bildirilmektedir (1-3). Tüberküloz menenjit, tüberkülozun en ağır formlarından biridir. Kesin tanısı; BOS'ta asido rezistan boyama ile tüberküloz basillerinin görülmesi, BOS kültüründe etkenin üretilmesi veya BOS'da PZR pozitifliği ile konmaktadır (4). Bu yazıda, varicella zoster ensefaliti ön tanısıyla asiklovir tedavisi alan, ancak tedaviye rağmen ateşi devam eden ve yapılan incelemeler sonucunda tüberküloz menenjit tanısı konulan bir olgu sunuldu. 


\section{OLGU}

Orbitofrontal bölgede zona tanısıyla üç gün süreyle oral valasiklovir tedavisi alan 58 yaşında erkek hasta, son iki gündür süren bilinç kaybı, uykuya meyil başağrısı şikayetiyle acil servise başvurmuş. Özgeçmişinde; diabet, hipertansiyon ve koroner arter hastalı̆̆ 1 mevcuttu. Daha önce akciğer tüberkülozu geçirme öyküsü yoktu. Fizik muayenesinde; vücut 1 sis1 $37,5^{\circ} \mathrm{C}$, kan basinc1 $140 / 70$ mmHg, oksijen saturasyonu $\left(\mathrm{SpO}_{2}\right) 93$ idi. Hastanın bilinci açık, kooperasyonu ve oryantasyonu kısıtlı idi. Ense sertliği, Kernig ve Brudzinski bulguları negatifti. Diğer sistem muayeneleri doğald. Laboratuvar testlerinde; lökosit sayısı $7000 / \mathrm{mm}^{3}$, CRP $39,9 \mathrm{mg} / \mathrm{L}$ (normali $0-5$ $\mathrm{mg} / \mathrm{L}$ ), sedimentasyon hızı $60 \mathrm{~mm} / \mathrm{saat}$ idi. Biyokimyasal testleri; serum Na $128 \mathrm{mmol} / \mathrm{L}$ (normali: 136-145 mmol/L) olup düşüktü, serum glukoz $190 \mathrm{mg} / \mathrm{dL}$ (normali: 70-100 mg/dL), AST $76 \mathrm{U} / \mathrm{L}$, ALT $63 \mathrm{U} / \mathrm{L}, \mathrm{D}$-dimer $4330 \mathrm{ng} / \mathrm{ml}$ (normali: 80-630 ng/ml) değerleri yüksekti. Hastanın antiHIV ELISA testi negatif, postereanterior akciğer grafisi normal olarak değerlendirildi.

Hastaya santral sinir sistemi enfeksiyonu ön tanısıla lomber ponksiyon yapıldı. Hücre sayımı, biyokimyasal testler, kültür, viral ve bakteriyel etkenlere yönelik PZR testi için BOS örneği alındıktan sonra, hastaya varicella zoster ensefaliti ön tanısıyla asiklovir 3×750 mg intravenöz yolla bașlandı. BOS’da, 220 lökosit, 1600 yeni eritrosit, 8000 eski eritrosit saptandı. BOS biyokimyasında glukoz $31 \mathrm{~g} / \mathrm{dL}$ (eş zamanlı kan glukozu $157 \mathrm{mg} / \mathrm{dL}$ ), BOS proteini 2445 mg/L (normali: 150-450 mg/L) idi. BOS kültüründe üreme olmadı. BOS'da viral ve bakteriyel PZR panelinde etken saptanmadi. Biyokimyasal testlerinde hiponatremi ( $\mathrm{Na}$ değeri $129 \mathrm{mmol} / \mathrm{L}$ ) saptanan hastaya dahiliye önerisi ile hipertansiyon için almakta olduğu ramipril kesilerek amlodipin tedavisi başlandı, hipertonik sodyum klorür replasmanı uygulandı. Tedavi ile hiponatremi düzeldi. Asiklovir tedavisi ile hastanın bilinç bulanıklığı ve uykuya eğilimi düzeldi. Tedavisinin 6 . gününde hasta kısa süreli nöbet geçirdi. Beyin bilgisayarlı tomografi (BT) ve elektroensefalografi (EEG) ile nörolojiye danışılan hastada akut patoloji düşünülmedi, BT ve EEG normal olarak değerlendirildi. Asiklovir tedavisinin 8. gününde vücut 1 sisı $39^{\circ} \mathrm{C}$ ye kadar yükseldi. Hastanın tedavisine ampirik olarak piperasilin tazobaktam $3 \times 4,5$ gr dozda intravenöz (i.v) yolla eklendi. Dahiliye kliniğine danışılan hastanın hiponatremisi övolemik hiponatremi olarak değerlendirildi. Tedaviye rağmen yüksek ateşi devam eden hastada, piperasilin-tazobaktam tedavisi kesildi, meropenem tedavisi $3 \times 1$ gr dozda i.v başlandı. Hastanın enfeksiyon odağı saptamaya yönelik yapılan testlerinde; ultrasonografi, ekokardiyogarfi incelemelerinde odak bulunamadı, nazofarengeal sürüntü örneğinde ise, Covid-19 PZR testi negatif saptand. İkinci kez lomber ponksiyon yapılan hastada travmatik hemorajik BOS mevcuttu. BOS'da hücre sayısı 2400 lökosit, yeni ve eski eritrositler saptandı. BOS glukozu 24 (eş zamanlı kan şekeri $150 \mathrm{mg} / \mathrm{dL}$ ), klor $109 \mathrm{mmol} / \mathrm{L}$, protein $1986 \mathrm{mg} / \mathrm{L}$, laktat 8,4 (normali: $<2,8 \mathrm{mmol} / \mathrm{L}$ ) idi. Meropenem tedavisine ampirik olarak vankomisin eklendi. Lomber ponksiyon öncesinde çekilen kontrastlı kraniyal manyetik rezonans görüntüleme (MRG)'de apse ve kontrastlanma saptanmadı BOS kültüründe, BOS'da bakteriyel ve viral etkenlere yönelik PZR testinde etken saptanmadı. BOS'da brusella aglütinasyon testi negatif saptand. Asiklovir tedavisi 14 güne tamamlanarak kesildi. Türkiye Halk Sağlığı Kurumu Tüberküloz Referans Laboratuvarína gönderilen BOS örneğinde PZR sonucu Mycobacterium tuberculosis complex olarak raporlandi. Meropenem ve vankomisin tedavinin 10. gününde kesilerek izoniyazid, pirazinamid, rifampin, etambutol ve deksametazon tedavisi başlandı. Kontrol tetkiklerinde lökosit sayısı $6100 / \mathrm{mm}^{3}$, CRP 9,2 $\mathrm{mg} / \mathrm{L}$ eritrosit sedimentasyon hız $25 \mathrm{~mm} / \mathrm{saat}$ olarak belirlendi. Antitüberküloz tedavinin 8 . gününde ateşi olmadı, klinik bulguları düzeldi, hasta kontrole gelmek üzere taburcu edildi.

\section{TARTIŞMA}

Santral sinir sistemi enfeksiyonları tüm dünyada önemli bir mortalite ve morbidite nedenidir. Tüberküloz menenjit, akciğer dışı tüberkülozun en ağır şekillerinden biridir. Kesin insidans ve prevalans bilinmemekle birlikte, akciğer tüberkülozu olgu sayısı yüksek olan ülkelerde, insidansın orantılı olarak yüksek olması beklenir (4). Tüberküloz menenjit tüberkülozlu hastaların yaklaşık \%1-5’inde görülür (5).

Baş ağrısı, kusma, meningeal irritasyon belirtileri (ense sertliği, Kernig, Brudzinski), fokal defisitler, görme kaybı, kraniyal sinir felci ve artmış kafa içi basıncı belirgin klinik özelliklerdir. Hastalardaki belirgin patolojik süreçler, meningeal inflamasyon, bazal eksüdalar, vaskülit ve hidrosefalidir. Tanısı, karakteristik klinik bulgular, BOS bulguları (BOS’ta artmış protein, düşük glikoz düzeyi ve lenfosit hakimiyeti) ve santral sinir sistemi görüntüleme bulgularındaki anormalliklere dayanmaktadır. BOS'ta EZN boyamada asido-rezistan basillerin görülmesi, etkenin kültürde üretilmesi veya PZR yöntemiyle saptanması bakteriyolojik doğrulama için zorunludur. Hastalığın mortalitesi ve morbiditesi son derece yüksektir, menenjit sonrası kalıcı sekellere neden olabilir. Hızlı tanısı ve erken tedavisi bu açıdan çok önemlidir. Antitüberküloz tedaviye başlama kararı genellikle ampiriktir. Antitüberküloz tedavinin 9 veya 12 ay süreyle uygulanması önerilmektedir. Tedaviye kortikosteroidler de eklenmelidir (4). Tedaviye rağmen, mortalite oranı erișkinlerde $\% 50$, çocuklarda $\% 20$ olarak bildirilmektedir (5). 
Sunduğumuz olguda uykuya meyil, bilinç kaybı olması ve orbital bölgede zona lezyonunun olması nedeniyle klinik olarak varicella zoster ensefaliti düşünüldü. Varicella zoster ensefalitine yönelik başlanan asiklovir tedavisi sonrası bilinç bulanıklığı ve uykuya meyil bulguları düzeldi. Tedavi esnasında hastanın ateşinin devam etmesi, başka bir enfeksiyon odağı saptanmaması, tedavi altında kısa süreli nöbet geçirmesi nedeniyle hastada başka bir santral sinir sistemi enfeksiyonu olabileceği düşünülerek lomber ponksiyon planlandi. Hastanın ateşinin olması ve BOS bulgularının tüberküloz menenjitle uyumlu olması üzerine istenilen BOS PZR sonucunun pozitif saptanması üzerine antitüberküloz tedavi ve kortikosteroid tedavisi başlandı.

Varicella zoster virüs, Herpesviridea ailesinde yer alan zarflı DNA virüsü olup, primer enfeksiyonu suçiçeği hastalığına, latent kalan virüsün reaktivasyonu sonucunda rekürren enfeksiyon şeklinde en sik zonaya neden olur. VZV reaktivasyonunun en sık ve önemli komplikasyonu nedeni tam bilinmeyen ve tedaviye genellikle yanıt alınamayan postherpetik nevraljidir. VZV'nin reaktivasyonu ayrıca çok çeșitli nörolojik sendromlara neden olabilir, bunlardan en önemlisi, kortikosteroidler ve antiviral ilaç asiklovir ile tedavi edilen bir vaskülittir. Diğer VZV reaktivasyon komplikasyonları arasında; ensefalit, segmental motor zayıflığı ve miyelopati, kraniyal nöropatiler, Guillain-Barré sendromu yer alır (3).

VZV ve HSV ensefalitinde polimeraz zincir reaksiyonu (PZR), tanı için altın standarttır ve ilk tercih görüntüleme yöntemi MRG'dir (6). Sunduğumuz olguda hastanın ensefalitle uyumlu bilinç değişiklikleri olması, orbitofrontal bölgede zonasinın olması nedeniyle hastadan PZR için BOS örneği alındıktan sonra asiklovir tedavisi başlandı.

Enfeksiyöz ensefalit insidansı, salgınlar dıșında, 1,57 vaka/100.000 kiși/yıl olarak tahmin edilmektedir. Enfeksiyöz ensefalit ve immün aracılı ensefalit, benzer klinik belirti ve semptomları paylaşır. HSV, çalışmaların \%65'inde en sık görülen patojendir ve bunu çeşitli çalışmalarda VZV izlemektedir (7).

İsviçre'de yapılan bir çalıșmada santral sinir sistemi enfeksiyonu etkeni olarak en sık görülen etkenler; Streptococcus pneumoniae, varicella zoster ve herpes simplex tip 1 ve 2 olarak rapor edilmiştir. Çalışmada,çok değişkenli analizde, laktat konsantrasyonları ve azalmış glukoz oranları, bakteriyel enfeksiyonun tek bağımsız prediktörleri iken, artmış CSF mononükleer hücreler, viral enfeksiyonların tek prediktörü olarak belirlenmiştir (8).

Birleșik Devletlerde HSV ve VZV santral sinir sistemi enfeksiyonu olan 98 erişkinin hastada klinik belirtiler, BOS incelemesi, görüntüleme bulguları ve olumsuz klinik sonuçlarla ilişkili prognostik faktörler araştırılmıştır. Çalışmada hastaların 25 'inde ensefalit [20 $(\% 20,4)$ HSV, $5(\% 5,1)$ VZV ensefaliti] ve 73'ünde menenjit saptanmıştır [60 $(\% 61,1)$ HSV ve $13(\% 13,3)$ VZV]. HSV ve VZV mide bulantısı ve döküntü dışında benzer bulgulara sahip olduğu, BOS özellikleri açısından HSV ve VZV enfeksiyonu arasında farklılık olmadığı bildirilmiştir. Anormal nörolojik görüntüleme bulguları, olguların \%11,6 (10/86) beyin bilgisayarlı tomografi (BT)'lerinde, \%21,3 (16/75)'ünde ise beyin manyetik rezonans görüntüleme (MRG)'lerinde saptanırken, elektroensefalografi, $\quad \% 57,9 \quad(11 / 19)$ 'da anormal saptanmıştır. Hastaların 16 (\%16,3)'sında olumsuz klinik sonuç bildirilmiştir (sırasıyla; $10 \mathrm{HSV}$ ensefaliti olgusunda, 3 VZV ensefaliti olgusunda ve 3 VZV menenjiti olgusunda). Hastalara 48 saat içinde uygulanan intravenöz asiklovir tedavisinin olumsuz klinik sonuçlara karşı önleyici olduğu saptanmıştır. Bununla birlikte, lojistik regresyon analizinde, sadece Charlson komorbidite skorunun 1'den büyük olması ve ensefalit prezentasyonu bağımsız olarak olumsuz istenmeyen durumlarla ilişkili saptanmıștır. Sonuç olarak, HSV ve VZV'ye bağlı santral sinir sistemi infesiyonlarının benzer klinik ve laboratuvar bulgularına sahip olduğu, komorbiditeleri ve ensefaliti olan hastalarda istenmeyen klinik sonuçların daha sık gözlendiği bildirilmiştir (9). Sunduğumuz olguda da BOS'da PZR negatif saptanması ve görüntüleme bulguları normal olmasına rağmen, klinik olarak VZV ensefaliti düşünülmüș ve antiviral tedavi ile hastanın bilinç kaybı, uykuya meyil ve başağrısı yakınmaları düzelmiştir.

Literatür tarandığı kadarıyla, varicella zoster ensefaliti ile tüberküloz menenjit birlikteliği sadece bir olguda bildirilmiştir (10). Sunduğumuz olgu, ingilizce literatür tarandığg kadarıla, VZV ensefaliti ile tüberküloz menenjit birlikteliğinin görüldüğü ikinci olgudur.

\section{SONUÇ}

Varicella zoster virus ensefaliti tedavisine rağmen ateşi ve klinik bulguları düzelmeyen ve başka bir enfeksiyon odağ saptanamayan olgularda Mycobacterium tuberculosis gibi başka bir etkenle birlikte santral sinir sistemi enfeksiyonu olabileceği akılda tutulmalıdır.

\section{ETIKK BEYANLAR}

Aydınlatılmış Onam: $\mathrm{Bu}$ çalışmaya katılan hastalardandan yazılı onam alınmıştır.

Hakem Değerlendirme Süreci: Harici çift kör hakem değerlendirmesi.

Çıkar Çatışması Durumu: Yazarlar bu çalışmada herhangi bir çıkara dayalı ilişki olmadığını beyan etmişlerdir. 
Finansal Destek: Yazarlar bu çalışmada finansal destek almadıklarını beyan etmişlerdir.

Yazar Katkıları: Yazarların tümü; makalenin tasarımına, yürütülmesine, analizine katıldığını ve son sürümünü onayladıklarını beyan etmişlerdir.

\section{KAYNAKLAR}

1. Whitley RJ. Chickenpox and herpes zoster (varicella zoster virus) In: Bennett JE, Dolin R, Blaser MJ, eds. Mandell, Douglas, and Bennett's Principles and Practice of Infectious Diseases. 8th ed. Philadelphia: Churchill Livingstone, 2015: 1731-7.

2. Büyükdemirci A, Yüksekkaya E, Cesur S, Kılıç EK, Hatipoğlu ÇA, Kınıklı S. Herpes zoster ophthalmicus sonrasında gelişen ensefalit olgusu. Klimik Derg 2018; 31: 157-60.

3. Peter G E Kennedy, Anne A Gershon. Clinical features of Varicella-Zoster virus infection. Viruses 2018; 10: 609.

4. Garg RK. Tuberculous meningitis. Acta Neurol Scand 2010; 122: 75-90.

5. Donovan J, Thwaites GE, Huynha J. Tuberculous meningitis: where to from here? Curr Opin Infect Dis 2020; 33: 259-66.

6. Stahl JP. Update on HSV and VZV infections of the brain. Rev Neurol (Paris) 2019; 175: 442-4.

7. Boucher A, Herrmann JL, Morand P, et al. Epidemiology of infectious encephalitis causes in 2016. Med Mal Infect 2017; 47: 221-35.

8. Dittrich T, Marsch S, Egli A, et al. Predictors of infectious meningitis or encephalitis: the yield of cerebrospinal fluid in a cross-sectional study. BMC Infect Dis 2020; 20: 304.

9. Kaewpoowat Q, Salazar L, Aguilera E, Wootton SH, Hasbun R Herpes simplex and varicella zoster CNS infections: clinical presentations, treatments and outcomes. Infection 2016; 44: 337 45.

10.Aibar-Arregui MA, de Escalante-Yangüela B, Tejero-Juste C, Martín-Fortea MP. Mixed meningoencephalitis caused by Mycobacterium tuberculosis and varicella zoster virüs. Rev Neurol 2009; 48: 91-3. 